\title{
EFEKTIVITAS PENERAPAN MEDIA PEMBELAJARAN INTERAKTIF DENGAN SOFTWARE AUTORUN UNTUK MENINGKATKAN KOMPETENSI FISIKA SISWA SMK NEGERI 1 PADANG
}

\author{
Usmeldi $^{1)}$ \\ ${ }^{1)}$ Teknik Elektro, FT Universitas Negeri Padang \\ usmeldi@ft.unp.ac.id
}

\begin{abstract}
Physics is one of the adaptive subjects in Vocational High School (SMK). Preliminary surveys of the implementation of learning physics at SMK Negeri 1 Padang shows that many students have not mastered the abstract concepts of physics, so students find it difficult to apply them in relevant productive subjects. Therefore, it is implemented physics learning with interactive learning media. This study aims to determine the effectiveness of interactive learning media to improve the student competence. The study used a quasi experimental method with a pretest-posttest control group design. The subjects of the research were students of eleventh grade in electrical engineering expertise program at SMK Negeri 1 Padang. Data were collected by using observation sheet, achievement test, and questionnaire of student responses to the implementation of learning. The result of the research shows that physics learning with interactive learning media is effective to improve the students' competence, in terms of (1) students' learning mastered has been achieved, (2) improvement of physics concept of experimental class in medium category, (3) The average score of mastery of the physics concept of the experimental class is higher than the control class, (4) most of the experimental class students stated that the implementation of physics learning with interactive learning media is good. Suggestion to physics teacher to conduct the computer assisted learning with interactive media.
\end{abstract}

Keywords : Interactive media, student's competence.

\section{PENDAHULUAN}

Information and Communication Technology (ICT) atau teknologi informasi dan komunikasi dalam beberapa dekade terakhir berkembang sangat cepat sejalan dengan perkembangan teknologi telekomunikasi, termasuk jaringan komputer. Berbagai teknologi dan aplikasi pendukung juga telah dikembangkan sebagai upaya untuk mendukung dan mempermudah aktivitas pembelajaran. Dalam menyikapi perkembangan dan kemajuan ICT tersebut, guru dituntut untuk menguasai ICT agar dapat mengembangkan materi pembelajaran berbasis ICT dan memanfaatkan ICT sebagai media pembelajaran. Tujuannya adalah untuk memberikan kemudahan dan kesempatan yang lebih luas kepada siswa dalam belajar. Dalam beberapa tahun terakhir, pemanfaatan ICT dalam dunia pendidikan sudah mulai memasyarakat, mulai dari jenjang pendidikan dasar, menengah, sampai ke perguruan tinggi, meskipun variasi dan fokus pemanfaatannya berbeda-beda pada masingmasing institusi. Banyak sekolah yang sudah melengkapi fasilitas ICT untuk mendukung proses pembelajaran.
Kehadiran dan kemajuan ICT pada saat ini telah memberikan perluasan interaksi antara guru, siswa, dan sumber-sumber belajar dapat terjadi kapan saja dan di mana saja tanpa dibatasi oleh ruang dan waktu. Selain itu, dengan bantuan ICT penyajian materi pembelajaran dapat menjadi lebih menarik dan menyenangkan. Di sisi lain, kehadiran ICT sebagai teknologi baru memberikan tantangan kepada guru untuk mampu menguasainya sehingga dapat memilih dan memanfaatkan ICT secara efektif dan efisien di dalam proses pembelajaran. Dalam hal ini, profesionalisme guru tidak hanya mencakup kemampuan membelajarkan siswa, tetapi juga kemampuan mengelola informasi dan lingkungan belajar (yang meliputi tempat belajar, metode, media, sistem penilaian, serta sarana dan prasarana) untuk memfasilitasi kegiatan belajar siswa sehingga menjadi lebih mudah (Ibrahim, dalam Santyasa, 2007). Oleh karena perkembangan ilmu pengetahuan dan teknologi, khususnya ICT, telah memperkaya sumber dan media pembelajaran dalam berbagai bentuk seperti buku teks, modul, transparansi OHP, slide power point, gambar/foto, animasi, film/video, siaran televisi, siaran radio, hyperteks, halaman web, program pembelajaran berbantuan komputer, 
dan software aplikasi pendukung pembelajaran, maka guru yang profesional harus mampu memilih, mengembangkan dan memanfaatkan berbagai jenis media pembelajaran dengan memanfaatkan kecanggian ICT tersebut. Kemajuan ICT juga telah memungkinkan memanfaatan berbagai jenis/macam media secara bersamaan dalam bentuk multimedia pembelajaran. Penggunaan multimedia interaktif yang memuat komponen audio-visual untuk penyampaian materi pembelajaran dapat menarik perhatian siswa untuk belajar. Multimedia interaktif juga dapat memberikan kesempatan kepada siswa untuk melakukan eksperimen semu dan eksplorasi sehingga memberikan pengalaman belajar daripada hanya sekedar mendengar penjelasan guru.

Berbagai upaya telah dilakukan oleh dunia pendidikan untuk meningkatkan kualitas pendidikan, khususnya kualitas pembelajaran melalui pemanfaatan ICT. Selain fungsinya sebagai alat bantu pemecahan masalah, ICT juga dapat dimanfaatkan untuk mendukung proses pembelajaran yang dipercaya dapat; (1) meningkatkan kualitas pembelajaran, (2) memperluas akses pembelajaran, (3) mengembangkan keterampilan ICT yang diperlukan siswa ketika bekerja dan dalam kehidupannya nanti (Krisnadi, 2009). Belajar melibatkan berbagai unsur yang ada di dalamnya, berupa kondisi fisik dan psikis orang yang belajar. Kedua kondisi tersebut akan sangat berpengaruh terhadap hasil belajarnya. Masih banyak unsur lain yang dapat berpengaruh terhadap hasil belajar, antara lain suasana lingkungan saat belajar, tersedianya media pembelajaran dan sebagainya. Oleh karena itu, unsur-unsur tersebut perlu mendapatkan perhatian untuk menunjang tercapainya tujuan belajar sesuai dengan yang diharapkan.

Untuk menunjang keberhasilan belajar, seharusnya tersedia media pembelajaran. Dengan tersedianya media pembelajaran, siswa dimungkinkan akan lebih berpikir secara konkret dan hal ini berarti dapat mengurangi verbalisme pada diri siswa. Hal demikian mengakibatkan siswa termasuk guru dapat memilih atau menggunakan media pembelajaran dalam proses belajar. Dalam proses pembelajaran kehadiran media mempunyai arti yang cukup penting. Karena dalam kegiatan tersebut ketidakjelasan materi ajar yang disampaikan dapat dibantu dengan menghadirkan media sebagai perantara. Kerumitan materi ajar yang akan disampaikan kepada siswa dapat disederhanakan dengan bantuan media. Media dapat mengatasi keterbatasan guru menyampaikan materi ajar melalui kata-kata atau kalimat. Bahkan keabstrakan materi ajar dapat dikonkretkan dengan kehadiran media pembelajaran, dengan demikian siswa lebih mudah memahami pelajaran daripada tanpa bantuan media pembelajaran.

Hamalik (1989) mengemukakan bahwa media pembelajaran mempunyai banyak istilah seperti istilah peragaan, komunikasi peragaan, audio visual aids, teaching material atau instruksional material. Oleh karena beragamnya istilah tersebut yang tekanannya berbeda, maka dipilih salah satu istilah yaitu media pembelajaran. Media pembelajaran adalah alat yang digunakan dalam rangka lebih mengefektifkan komunikasi dan interaksi antara guru dengan siswa dalam proses pembelajaran di sekolah. Penggunaan suatu media dalam pelaksanaan pembelajaran bagaimanapun akan membantu kelancaran dan pencapaian tujuan, sehingga dapat menjadikan siswa asyik belajar, menyenangkan dan sudah tentu pembelajaran benar-benar akan menjadi bermakna. Media merupakan salah satu komponen sistem pembelajaran yang tidak bisa diabaikan dalam pengembangan sistem pembelajaran. Hamalik (1989) mengemukakan bahwa pemakaian media dalam pembelajaran dapat membangkitkan keinginan, minat, motivasi dan rangsangan kegiatan belajar, bahkan membawa pengaruh psikologis terhadap siswa. Penggunaan media pendidikan janganlah sekedar dianggap sebagai upaya membantu guru yang bersifat pasif, artinya penggunaanya semata-mata ditentukan oleh guru. Melainkan merupakan upaya membantu siswa untuk belajar.

Seorang guru tentu saja harus dapat menerapkan media apa yang paling tepat dan sesuai untuk tujuan tertentu, penyampaian bahan tertentu, suatu kondisi belajar siswa, dan untuk penggunaan strategi atau metode yang memang telah terpilih. Berbagai jenis media pembelajaran penting diketahui oleh guru dan akan lebih baik lagi jika guru memiliki kemampuan membuat media pembelajaran yang dibutuhkannya. Sudjana (2009) menyatakan bahwa media pembelajaran dapat meningkatkan proses pembelajaran yang pada gilirannya dapat meningkatkan hasil belajar siswa. Taraf berpikir manusia mengikuti tahap perkembangan dimulai dari berpikir sederhana menuju berpikir abstrak, dimulai dari berpikir sederhana menuju ke berpikir kompleks. Penggunaan media pembelajaran erat kaitannya dengan tahapan berpikir tersebut, sebab melalui media pembelajaran hal-hal yang ab- 
strak dapat dikonkretkan, dan hal-hal yang kompleks dapat disederhanakan. Menurut Arsyad (2009) fungsi utama media pembelajaran adalah sebagai alat bantu mengajar yang turut mempengaruhi iklim, kondisi, dan lingkungan belajar yang ditata dan diciptakan oleh guru.

Penggunaan media pada tahap orientasi pembelajaran akan sangat membantu keefektifan proses penyampaian pesan dan isi pelajaran pada saat itu. Selain membangkitkan motivasi dan minat, media pembelajaran juga dapat membantu siswa meningkatkan pemahaman, menyajikan data dengan menarik dan terpercaya, memudahkan penafsiran data, dan memadatkan informasi.

Dalam pemanfaatan media pembelajaran dengan komputer dikenal dengan istilah Computer Assisted Instruction (CAI). Dalam pemanfaatan media komputer meskipun komputer tidak dapat menggantikan proses pembelajaran dengan tatap muka, namun antara siswa dengan komputer dapat berkomunikasi dan terjadi interaksi secara mandiri, dengan demikian dapat menghasilkan sebuah hasil belajar yang efektif. Secara umum CAI dalam proses pembelajaran memiliki dua peranan, yakni (1) Sebagai tutor pengganti. Pada jenis ini para siswa dapat berpartisipasi dalam suatu dialog secara interaktif. Dalam model ini para siswa berinteraksi langsung dengan komputer yang diprogram secara khusus untuk memberikan reaksi atau respon dari stimulus atau aktivitas yang dilakukan oleh seorang siswa terhadap pertanyaan-pertanyaan yang telah disiapkan. Komputer tersebut kemudian dapat menyediakan informasi belajar tambahan sebagai pelengkapnya, yang selanjutnya menghendaki adanya jawaban segera oleh para siswa yang bersangkutan. (2) Sebagai laboratorium stimulasi, yang menyediakan kemudahan bagi siswa dalam melaksanakan eksperimen berdasarkan sistem model yang telah diprogramkan ke dalam komputer melalui CAI. CAI memiliki keluwesan dan kemampuan untuk memberikan pelajaran dan penanaman konsep secara bervariasi, maka model tersebut dianggap sebagai seorang tutor pengganti yang sabar tanpa batas sekaligus dapat memberikan bantuan kepada para siswa bahan referensi yang diperlukan dan menarik perhatian serta kreativitas siswa.

Metode pembelajaran mempunyai karakteristik masing-masing. Oleh sebab itu pemilihan metode yang tepat dalam pembelajaran perlu dilakukan oleh guru untuk mencapai tujuan pembelajaran. Salah satu metode pembelajaran yang dapat diintegrasikan dengan media komputer adalah metode pembelajaran berbantuan komputer (CAI).

Pembelajaran fisika yang dilakukan di sekolah sudah menggunakan media komputer sebagai media presentasi, belum digunakan untuk media interaktif. Hal ini terlihat dari observasi yang dilakukan pada pembelajaran fisika di SMK Negeri 1 Padang ditemukan bahwa pembelajaran fisika masih berpusat pada guru. Pada ranah kognitif, hasil belajar fisika siswa masih rendah. Hal ini ditunjukkan oleh banyaknya siswa $(65 \%)$ yang belum mencapai kriteria ketuntasan minimum yaitu 70 . Rendahnya hasil belajar siswa disebabkan oleh beberapa hal, yaitu pembelajaran fisika belum menyenangkan, belum menarik, dan belum menantang bagi siswa. Dalam proses pembelajaran, siswa belum dilibatkan secara aktif dalam menemukan fakta, konsep, dan prinsip yang dapat diterapkan untuk memecahkan masalah dalam mata pelajaran produktif dan dalam kehidupan sehari-hari. Salah satu upaya untuk meningkatkan kompetensi siswa adalah melaksanakan pembelajaran dengan media interaktif yang dibuat dengan software autorun. Software autorun adalah program komputer untuk membuat media pembelajaran interaktif dengan mudah dibandingkan dengan program lain, karena dapat diintegrasikan dengan berbagai file aplikasi seperti word, pdf, macromedia flash, video dan audio.

Berdasarkan pada kondisi pembelajaran fisika yang telah diuraikan di atas maka perlu dilakukan penelitian untuk meningkatkan kompetensi fisika siswa. Masalah dalam penelitian dirumuskan sebagai berikut: Bagaimana efektivitas penggunaan media pembelajaran interaktif dengan software Autorun untuk meningkatkan kompetensi fisika siswa? Penelitian ini bertujuan untuk mengungkapkan efektivitas penggunaan media pembelajaran interaktif dengan software Autorun untuk meningkatkan kompetensi fisika siswa.

\section{METODE PENELITIAN}

Penelitian ini menggunakan metode eksperimen kuasi dengan desain pretest-posttest grup kontrol (Creswell, 1994). Pre-test dan posttest diberikan pada siswa kelas eksperimen dan kelas kontrol dengan menggunakan soal yang sama. Penelitian dilaksanakan pada siswa siswa kelas XI program keahlian Teknik Ketenagalistrikan di SMK Negeri 1 Padang dalam mata pelajaran Fisika. Materi fisika yang disajikan 
dalam penelitian adalah listrik statis sebanyak 4 materi pokok. Langkah-langkah penelitian adalah: (1) melakukan survei pendahuluan, (2) membuat media pembelajaran interaktif dengan software autorun, (3) memvalidasi media pembelajaran interaktif, (4) menyusun instrumen penelitian, (5) melakukan ujicoba media pembelajaran interaktif dan instrumen penelitian, (6) menganalisis data uji coba, (7) memberikan pretest pada siswa kelas eksperimen dan kelas kontrol, (8) memberikan perlakuan pada siswa kelas eksperimen dengan melaksanakan pembelajaran fisika berbantuan komputer dan media pembelajaran interaktif, sedangkan siswa kelas kontrol melaksanakan pembelajaran konvensional, (9) memberikan post-test pada siswa kelas eksperimen dan kelas kontrol, (10) menganalisis data dan menginterpretasi hasil yang diperoleh. Media pembelajaran interaktif yang digunakan dalam penelitian ini dibuat oleh peneliti, dengan langkah-langkah: (1) perancangan, (2) pembuatan program, (3) validasi media pembelajaran interaktif, (4) uji coba media pembelajaran interaktif.

Instrumen yang digunakan dalam penelitian berupa: format observasi, tes penguasaan konsep fisika, dan angket tanggapan siswa terhadap pelaksanaan pembelajaran. Format observasi digunakan sebagai pedoman dalam melakukan survei pendahuluan. Tes penguasaan konsep fisika berbentuk tes esei dengan mengutamakan pertanyaan tentang konsep fisika daripada penyelesaian soal-sal berupa perhitungan dengan menggunakan rumus-rumus fisika. Naskah soal ini disusun oleh peneliti dengan bantuan penimbang ahli (expert judgement) untuk mengetahui validitas isi tes. Validitas konstruksi dan reliabilitas tes diperoleh melalui uji coba instrumen penelitian.

Data penguasaan konsep fisika dianalisis secara kuantitatif untuk mengetahui penguasaan konsep fisika siswa dalam pembelajaran. Peningkatan penguasaan konsep fisika siswa dianalisis dengan menghitung rata-rata skor gain dinormalisasi $(<\mathrm{g}\rangle)$ dari skor pre-test dan posttest. Perbedaan rata-rata skor penguasaan konsep fisika siswa kelas eksperimen dan kelas kontrol dianalisis dengan menggunakan uji-t. Data tanggapan siswa terhadap pelaksanaan pembelajaran dianalisis dengan membandingkan rata-rata skor dengan kategori skor. Efektivitas penerapan pembelajaran ditinjau dari kompetensi siswa pada ranah kognitif. Ketuntasan belajar siswa berdasarkan kriteria ketuntasan minimum
(70). Secara klasikal persentase siswa yang tuntas dalam belajar diharapkan minimum sebesar $85 \%$.

\section{HASIL DAN PEMBAHASAN}

\section{Media Interaktif}

Media interaktif dibuat dengan software autorun dikemas dalam bentuk compact disk yang dapat dijalankan tanpa install software autorun di komputer, diawali dengan tampilan menu (Gambar 1) dilanjutkan sampai ke sub menu kegiatan belajar dan latihan (Gambar 2, 3, 4).

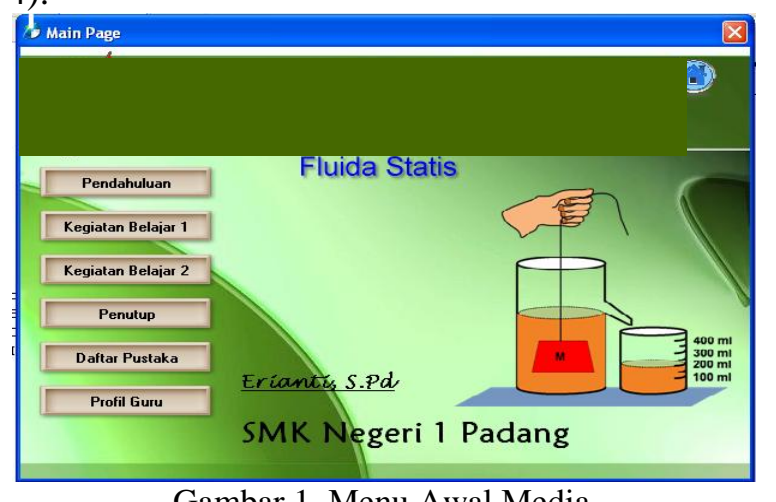

Gambar 1. Menu Awal Media

Pembelajaran Interaktif

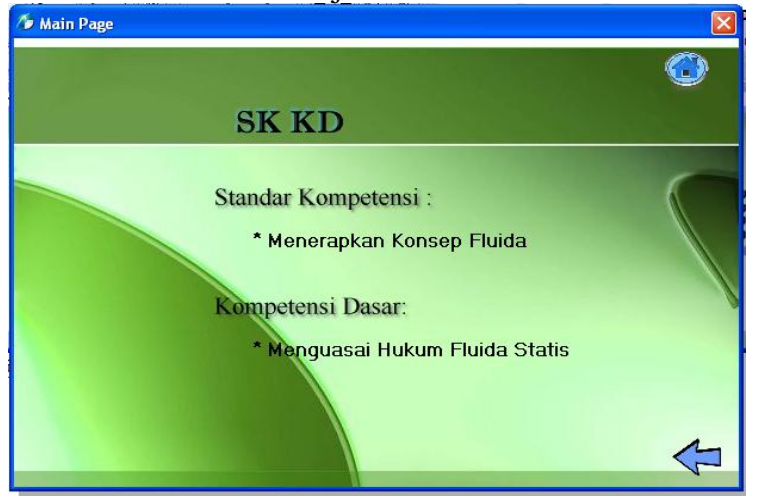

Gambar 2. Sub Menu dari Menu Pendahuluan

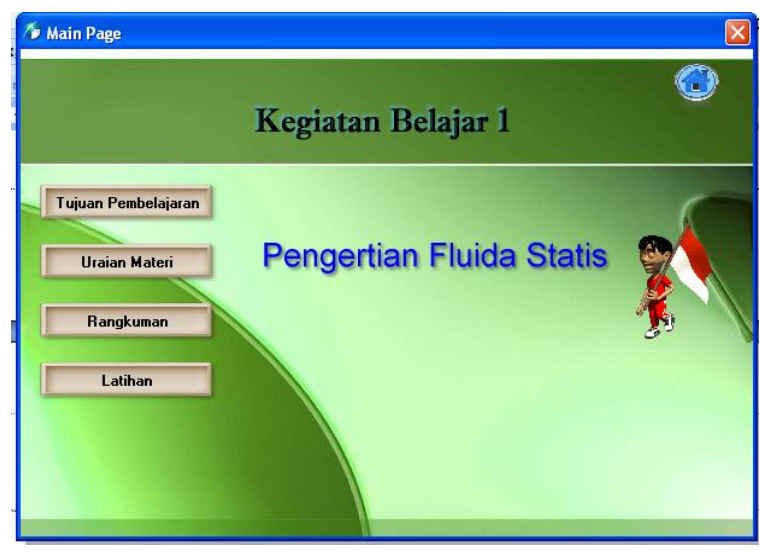

Gambar 3. Menu Kegiatan Belajar 1 


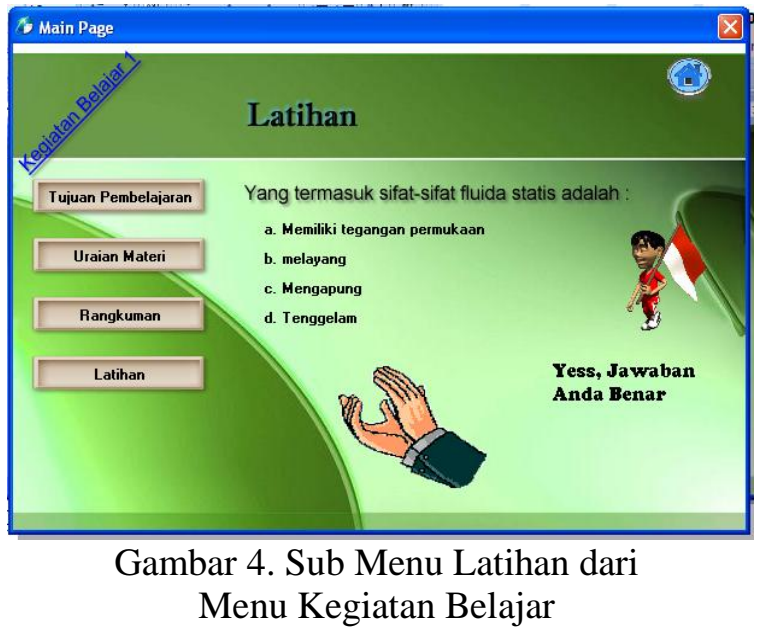

Efektivitas penggunaan media pembelajaran interaktif dalam meningkatkan hasil belajar siswa ditinjau dari: (1) ketuntasan belajar siswa kelas eksperimen, (2) peningkatan hasil belajar siswa kelas eksperimen, (3) perbedaan rata-rata skor hasil belajar siswa kelas eksperimen dan kelas kontrol, (4) tanggapan siswa terhadap pelaksanaan pembelajaran.

\section{Ketuntasan Belajar Siswa}

Penilaian terhadap kompetensi siswa kelas eksperimen pada ranah kognitif, diperoleh rata-rata nilai post-test sebesar 75,27 dengan persentase jumlah siswa yang tuntas belajarnya adalah $88,5 \%$. Ketuntasan belajar siswa secara klasikal sudah dicapai. Kompetensi siswa pada ranah kognitif dapat meningkat karena siswa dapat memahami konsep-konsep fisika dengan baik. Siswa dapat berpikir kritis dan kreatif karena permasalahan fisika yang ditampilkan berkaitan dengan bidang keahlian teknik ketenagalistrikan dan lingkungan sekitar siswa.

\section{Peningkatan Hasil Belajar Siswa}

Rata-rata pre-test fisika siswa kelas eksperimen diperoleh 64,76 dengan standar deviasi 8,29. Rata-rata hasil belajar siswa kelas kontrol diperoleh 63,65 dengan standar deviasi 4,13. Rata-rata post-test fisika siswa kelas eksperimen diperoleh 82,88 dengan standar deviasi 6,85. Rata-rata hasil belajar siswa kelas kontrol diperoleh 67,75 dengan standar deviasi 5,24 .

Peningkatan hasil belajar siswa dapat diketahui dengan menghitung rata-rata skor gain dinormalisasi dari skor pre-test dan post-test. Setelah melalui proses analisis data skor pre-test dan post-test, diperoleh rata-rata skor $\langle\mathrm{g}\rangle$ untuk hasil belajar siswa kelas eksperimen sebesar 0,45 dan standar deviasi sebesar 0,27.
Berdasarkan kategori skor gain dinormalisasi, peningkatan hasil belajar siswa kelas eksperimen dalam pelajaran fisika termasuk kategori sedang. Untuk siswa kelas kontrol diperoleh rata-rata skor $\langle\mathrm{g}\rangle$ sebesar 0,23 dan standar deviasi sebesar 0,18. Peningkatan hasil belajar siswa kelas kontrol termasuk kategori rendah.

\section{Perbedaan Hasil Belajar Siswa Kelas Eksperimen dan Kelas Kontrol}

Sebelum menganalisis data untuk mengetahui perbedaan rata-rata skor hasil belajar siswa kelas eksperimen dan kelas kontrol, dengan menggunakan uji-t, terlebih dahulu dilakukan uji normalitas distribusi data dan uji homogenitas data. Uji normalitas distribusi data dan uji homogenitas data merupakan uji persyaratan analisis data untuk menentukan rumus uji-t yang digunakan. Hasil uji normalitas distribusi data menunjukkan bahwa data pre-test dan post-test fisika siswa kelas eksperimen dan kelas kontrol berdistribusi normal pada taraf signifikansi $\alpha=0,05$. Hasil uji homogenitas data menunjukkan bahwa data pretest fisika siswa kelas eksperimen dan kelas kontrol adalah homogen $(\alpha=0,05)$, demikian juga data post-test fisika.

Berdasarkan hasil uji normalitas distribusi data dan uji homogenitas data hasil belajar siswa kelas eksperimen dan kelas kontrol maka dapat ditetapkan bahwa uji beda rata-rata skor hasil belajar siswa dapat menggunakan uji-t (dengan rumus untuk data normal dan homogen). Setelah dilakukan uji beda rata-rata terhadap data hasil belajar siswa diperoleh hasil bahwa rata-rata skor pre-test fisika bagi siswa kelas eksperimen dan kelas kontrol tidak berbeda secara signifikan $(\alpha=0,05)$. Dengan demikian dapat dikatakan bahwa hasil belajar fisika siswa sebelum belajar fisika dimulai adalah sama dalam kedua kelas tersebut. Uji beda rata-rata skor post-test fisika menunjukkan bahwa rata-rata skor post-test fisika bagi siswa kelas eksperimen dan kelas kontrol berbeda secara signifikan $(\alpha=0,05)$. Dengan demikian dapat dikatakan bahwa hasil belajar siswa sesudah belajar fisika menjadi berbeda dalam kedua kelas tersebut. Rata-rata skor hasil belajar fisika bagi siswa kelas eksperimen lebih tinggi daripada kelas kontrol. Hasil uji beda rata-rata skor hasil belajar fisika bagi siswa kelas eksperimen dan kelas kontrol untuk kelompok uji pre-test dan post-test dapat dilihat pada Tabel 1 . 
Tabel 1. Hasil Uji Beda Rata-rata Skor Hasil Belajar Fisika bagi Siswa Kelas Eksperimen dan Kelas Kontrol

\begin{tabular}{lllll}
\hline $\begin{array}{l}\text { Kelompok } \\
\text { Uji }\end{array}$ & $\begin{array}{l}\text { Kelompok } \\
\text { Perlakuan }\end{array}$ & $\begin{array}{l}\text { Rata- } \\
\text { rata }\end{array}$ & $\begin{array}{l}\text { Nilai } \\
\mathrm{t}_{\text {hitung }}\end{array}$ & Ket \\
\hline Pre-test & Eksperimen & 64,76 & 0,852 & Tidak \\
& Kontrol & 63,65 & & Sign \\
Post-test & Eksperimen & 82,88 & 5,938 & Sign \\
& Kontrol & 67,75 & & \\
\hline Nilai $\mathrm{t}_{\text {tabel }}=2,000$ & & &
\end{tabular}

Visualisasi dari perbedaan rata-rata skor pre-test dan post-test fisika siswa dalam Tabel 1 dapat dilihat pada Gambar 5.

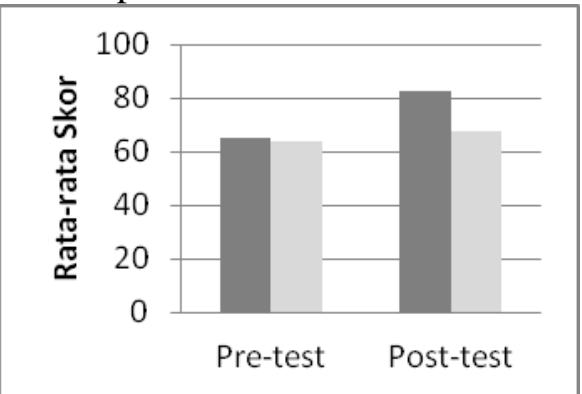

Gambar 5. Perbedaan Hasil Belajar Siswa (Hitam=kelas eksperimen, abu-abu=kelas kontrol)

\section{Tanggapan Siswa terhadap Pelaksanaan Pembelajaran}

Hasil analisis data tanggapan siswa terhadap pelaksanaan pembelajaran menunjukkan bahwa rata-rata skor tanggapan sebesar 73 dengan standar deviasi sebesar 4,7 dan termasuk kategori baik. Kategori skor tanggapan siswa diperoleh berdasarkan rata-rata skor ideal dan standar deviasi ideal.

Berdasarkan hasil analisis data yang telah diuraikan di atas dapat ditunjukkan bahwa: (1) ketuntasan belajar siswa secara klasikal sudah dicapai sebesar $88,5 \%$, (2) terdapat peningkatan yang signifikan pada penguasaan konsep fisika siswa kelas eksperimen, (3) terdapat perbedaan yang signifikan antara rata-rata skor penguasaan konsep fisika siswa kelas eksperimen dan kelas kontrol, rata-rata skor penguasaan konsep fisika siswa kelas eksperimen lebih tinggi daripada rata-rata skor penguasaan konsep fisika siswa kelas kontrol, (4) sebagian besar siswa kelas eksperimen menganggap bahwa pelaksanaan pembelajaran fisika dengan media interaktif termasuk kategori baik. Dengan demikian dapat disimpulkan bahwa pembelajaran dengan menggunakan media interaktif efektif untuk meningkatkan penguasaan konsep fisika siswa.
Temuan penelitian ini didukung oleh penelitian yang sudah dilakukan oleh Salim (2011) menyimpulkan bahwa pembelajaran menggunakan media pembelajaran macromedia flash efektif untuk meningkatkan hasil belajar fisika siswa. Cepi (2003), Mukhtadin (2015), dan Somnuek (2014) menyatakan bahwa media interaktif dapat digunakan pada pembelajaran karena efektif untuk meningkatkan hasil belajar. Media interaktif memiliki unsur-unsur media yang meliputi: suara, animasi, video, teks, dan grafik yang berpengaruh terhadap kinerja/ daya serap siswa terhadap materi yang disampaikan. Penggunaan media pembelajaran macromedia flash pada pembelajaran fisika dapat meningkatkan hasil belajar siswa (Wahyudi, 2009).

\section{KESIMPULAN}

Hasil penelitian menunjukkan bahwa pembelajaran fisika dengan media pembelajaran interaktif efektif dalam meningkatkan penguasaan konsep fisika, yang ditinjau dari: (1) ketuntasan belajar siswa secara klasikal sudah dicapai, (2) peningkatan penguasaan konsep fisika siswa kelas eksperimen, (3) perbedaan rata-rata skor penguasaan konsep fisika siswa kelas eksperimen dan kelas kontrol, (4) tanggapan siswa terhadap pelaksanaan pembelajaran. Dalam penelitian ini ditemukan bahwa peningkatan penguasaan konsep fisika siswa kelas eksperimen termasuk kategori sedang. Peningkatan penguasaan konsep fisika siswa kelas kontrol termasuk kategori rendah. Terdapat perbedaan yang signifikan antara ratarata skor penguasaan konsep fisika siswa kelas eksperimen dan kelas kontrol. Rata-rata skor penguasaan konsep fisika siswa kelas eksperimen lebih tinggi daripada kelas kontrol. Penguasaan konsep fisika siswa kelas eksperimen termasuk kategori baik.

\section{DAFTAR PUSTAKA}

Arsyad, A. 2009. Media Pembelajaran. Jakarta: Rajawali Pers.

Cepi, R. 2003. CD Interaktif sebagai Media Pembelajaran. Jakarta: PT. Elex Media Komputindo.

Creswell, J.W. 1994. Research Design: Qualitative and Quantitative Aproaches. New Delhi: SAGE Publications.

Hamalik, Oemar. 1989. Media Pendidikan. Bandung: Citra Aditya.

Krisnadi, E. 2009. Rancangan Materi Pembelajaran Berbasis ICT. Makalah disajikan da- 
lam Workshop Pengembangan Materi Pembelajaran Berbasis ICT di FMIPA UNY.

Mukhtadin, R., Suyitno. 2015. Pengembangan Media CD Interaktif Pembelajaran Otomotif Materi Sistem Rem pada Siswa Kelas XI SMK Plus Nururrohmah Kuwarasan. Jurnal Pendidikan Teknik Otomotif, Universitas Muhammadiyah Purworejo. 5 (22).

Salim,A., Ishafit, dan Moh.Toifur. 2011. Pemanfaatan Media Pembelajaran (Macromedia Flash) dengan Pendekatan Kontruktivis dalam Meningkatkan Efektivitas Pembelajaran Fisika pada Konsep Gaya. Prosiding Seminar Nasional Penelitian, Pendidikan dan Penerapan MIPA. Yogyakarta: UNY. F-279 - F-284

Santyasa, I.W. 2007. Landasan Konseptual Media Pembelajaran. Makalah disajikan dalam Workshop Media Pembelajaran bagi GuruGuru SMA Negeri Banjar Angkan di Banjar Angkan Klungkung.

Somnuek, P. 2014. The Development of Teaching and Learning Innovation by Using Instructional Media for Enhancement of Learning Achievement towards Tourism Product Knowledge in Tourism Marketing Class. SHS Web of Conferences.

Sudjana, Nana dan Ahmad Rivai. 2009. Media Pengajaran. Bandung: Sinar Baru Algensindo.

Wahyudi. 2009. Pemanfaatan Media Animasi Macromedia Flash untuk Meningkatkan Hasil Belajar Siswa Kelas XB Teknik Gambar Bangunan SMK Negeri 2 Wonogiri. Jurnal Dadiktika, Edisi Khusus Hardiknas, 143-151. 